\title{
EVALUASI KEBIJAKAN KEPALA MADRASAH DALAM MENINGKATKAN PROFESIONALITAS GURU MAS AL- MANSHURIYAH
}

\author{
Selamat Tulipri ${ }^{1}$, Rahmat Hidayat ${ }^{2}$, \\ Hamengkubuwono ${ }^{3}$, Jumira Warlizasusi ${ }^{4}$ \\ Institut Agama Islam Negeri (IAIN) Curup ${ }^{1,2,3,4}$ \\ Levri2020@gmail.com
}

\begin{abstract}
ABSTRAK
Tujuan penelitian ini adalah untuk mengetahui evaluasi kebijakan kepala madrasah dalam meningkatkan profesionalitas guru MAS Al-Manshuriyah. Penelitian ini merupakan jenis penelitian kualitatif yaitu suatu Pendekatan Penelitian yang menghasilkan data dekriptif berupa data-data tertulis atau lisan dari orang-orang dan pelaku yang diamati. Adapun bentuk penelitiannya adalah deskriptif yaitu penelitian yang dilakukanhanya bertujuan untuk menggambarkan keadaan atau status fenomena dalam situasi tertentu. Hasil penelitian, evaluasi kebijakan kepala sekolah dalam meningkatkan professional guru dalam menjalankan tugas sangatlah penting sekali, sebab melalui kebijakan yang tepat, maka akan berdampak pada peningkatan kualitas guru dalam menjalankan tugasnya dengan baik, namun jika kebijakan yang dibuat kurang tepat, maka akan berdampak pada peningkatan kualitas guru dalam menjalankan tugasnya dengan baik. Simpulan, Kebijakan kepala sekolah dalam meningkatkan professional guru dalam menjalankan tugasnya berjalan dengan baik, namun ada sedikit yang perlu diperbaruai sehingga kebijakan tersebut dapat berjalan dengan baik, yakni pemberian sanksi yang tepat, peran pengawas sekolah dan musyawarah dalam menerapkan kebijakan terutama dalam meningkatkan professional guru dalam menjalankan tugas pokok dan fungsinya dengan baik
\end{abstract}

Kata Kunci: Evaluasi Kebijakan, Profesionalitas

\begin{abstract}
The purpose of this study was to study the evaluation of the headmaster in improving the professionalism of MAS Al-Manshuriyah teachers. This research is a type of qualitative research consisting of research that produces descriptive data in the form of written or oral data from people and published. The form of the research is descriptive, that is the research conducted only to describe the state or status of a particular phenomenon. The results of the study, evaluation of the principal's policy in increasing the professionalism of teachers in carrying out their important tasks, appropriate policy considerations, will have an impact on improving the quality of teachers in carrying out their duties properly, but if the policies made are less precise, it will have an impact on improving the quality of teachers in carry out their duties properly. Conclusion, the principal's policy in increasing professional teachers in carrying out their duties went well, but there are some things that need to be updated, as well as policies that can be carried
\end{abstract}


out properly, namely giving appropriate approval, the role of school supervisors and deliberations in relation to changes policies in improving teacher professionalism in carrying out their main tasks and functions properly

Keywords: Policy Evaluation, Professionalism

\section{PENDAHULUAN}

Pada prinsipnya sumber daya manusia adalah satu-satunya sumber daya yang menentukan organisasi termasuk organisasi sekolah. Sumber daya manusia dipahami sebagai kekuatan yang bersumber dari potensi manusia yang ada dalan organisasi, dan merupakan model dasar organisasi untuk melakukan aktivitas dalam mencapai tujuan. Sumber daya manusia sering disebut human resource, tenaga atau kekuatan manusia (Fathoni, 2006)

Sumber daya manusia adalah manusia yang bekerja dilingkungan organisasi, disebut sebagai personal, tenaga kerja, pegawai atau karyawan Lembaga pendidikan formal atau yang disebut dengan sekolah atau madrasah merupakan pranata sosial yang mengalami perkembangan dari masa ke masa yang biasanya diselenggarakan secara masal untuk umum dengan standar kurikulum tertentu pada jenjang dan jenis pendidikan tertentu. Dikarenakan pendidikan merupakan pranata sosial, maka keterlibatan masyarakat dalam proses pendidikan menjadi mutlak diperlukan sebagaimana tertuang dalam paradigma baru tri pusat pendidikan dimana semua orang (orang tua dalam keluarga, kepala sekolah dan guru di sekolah serta masyarakat) bekerjasama mendidik anak-anak dengan baik.

Didunia pendidikan tujuan manajemen SDM lebih mengarah pada pembangunan pendidikan yang bermutu, membentuk SDM yang handal, produktif, kreatif dan berprestasi. Hingga dalam menjalankan tugas dan fungsinya secara profesional tenaga pendidik dan kependidikan harus memiliki kompetensi yang disyaratkan baik oleh peraturan pemerintah maupun kebutuhan masyarakat antara lain : (1) pendidik harus memiliki kualifikasi minimum dan sertivikasi sesuai dengan jenjang kewenangan mengajar, sehat jasmani dan rohani, serta memiliki kemampuan untuk mewujudkan tujuan pendidikan nasional, (2) pendidik untuk pendidikan formal pada jenjang pendidikan usia dini, pendidikan dasar, pendidikan menengah, dan pendidikan tinggi dihasilkan oleh perguruan tinggi yang terakreditasi (Tim Dosen Administrasi UPI, 2022)

Membicarakan sumber daya manusia tidak lepas dari sekolah, dan masyarakat dalam hal perencanaan, implementasi, monitoring, dan evaluasi program kerja yang dilakukan di sekolah (Pidarta, 2011). Menurut UU Nomor 14 Tahun 2005 tentang Guru dan Dosen Pasal 1 Guru adalah pendidik profesional dengan tugas utama mendidik, mengajar, membimbing, mengarahkan melatih, menilai, dan mengevalusi peserta didik pada pendidikan anak usia dini jalur pendidikan formal, pendidikan dasar, dan pendidikan menengah (Hamalik, 2009)

Dalam Peraturan Menteri Pendidikan Nasional RI Nomor 16 Tahun 2007

tentang Standar Kompetensi Akademik dan Kompetensi Guru dijelaskan bahwa 
kualifikasi akademik guru SD/MI, SMP/MTs, dan SMA/MA minimum diploma empat (D-4) atau sarjana (S-1). Dalam peraturan Menteri Pendidikan Nasional juga disebutkan bahwa "Guru harus menguasai empat kompetensi utama guna melaksanakan profesinya agar mencapai hasil yang memuaskan. Kompetensi tersebut yaitu : 1) kompetensi pedagogik, 2) kompetensi kepribadian, 3) kompetensi sosial, dan 4) kompetensi profesional

Dengan demikian baik tidaknya guru dapat telihat dari kompeten dalam melaksanakan kompetensi-kompetensi yang harus dimiliki oleh seorang guru disamping kualifikasi akademik. Artinya dengan segenap kemampuannya, guru harus menunjukkan kinerjanya secara optimal dan bekerja secara professional agar keberhasilan pembelajaran dapat tercapai. Kinerja guru mempunyai spesifikasi yang dapat dilihat dan diukur berdasarkan spesifikasi/variable yang harus dimiliki oleh setiap guru berkaitan dengan kinerja guru, wujud prilaku yang dimaksud adalah kegiatan guru dalam proses pemb lajaran yaitu bagaimana seorang guru merencanakan pembelajaran, melaksanakan pembelajaran dan mengevaluasi hasil belajar.

Sebagian besar hasil belajar peserta didik ditentukan oleh peranan guru. Kinerja guru adalah proses kerja yang dilakukan seseorang guru berdasarkan kemauan dan kemampuannya dalam melaksanakan tugas yang dibebankan kepadanya secara jelas dan relevan serta dapat diminta hasilnya baik secara kualitas maupun kuantitas. Kinerja guru menyangkut seluruh aktivitas yang dilakukan dalam mengemban amanat dan tanggung jawab dalam mendiidk, mengajar, membimbing, mengarahkan, dan memandu siswa dalam mencapai tingkat kedewasaan dan kematangan (Usman, 1995)

Terkait dengan indikator kinerja guru diatas, guru MAS Aliyah Manshuriyah Sungai Baung dapat dikatakan sudah berjalan baik, namun belum efektif, hal ini dapat diketahui berdasarkan observasi sementara yang peneliti lakukan pada tanggal 20 Februari 2019, menunjukkan bahwa guru belum sepenuhnya memiliki kompetensi yang baik terutama dalam mengelola program pembelajaran, hal ini dikarenakan faktor-faktor yang masih mempengaruhi pelaksanaan pelatihan dan pengembangan profesionalisme guru yang belum optimal.

MAS Aliyah Manshuriyah Sungai Baung memiliki susunan personalia dalam pengelolaan sekolah seperti kepala madrasah, komite madrasah, bidang humas, tata usaha, pengembangan diri, sarana dan prasarana, kurikulum, dan keuangan. Jumlah tenaga pendidik sebanyak 23 pendidik, dan 5tenaga kependidikan. Tugas personalia adalah berusaha untuk mencapai tujuan sekolah, termasuk selalu berusaha meningkatkan kompetensi profesional mereka. beberapa pengembangan terhadap guru di MAS Aliyah Mnshuriyah Sungai Baung sudah dilakukan oleh pemerintah, diantaranya adanya program peningkatan kualifikasi guru bahwa kualifikasi pendidikan guru adalah minimal S1 dari program keguruan tetapi masih ada guru yang belum memenuhi ketentuan tersebut, oleh 
karenanya pengembangan profesionalisme guru diperuntukkan bagi semua guru yang ada.

Selanjutnya dilakukan pula upaya pengembangan pada program penyetaraan dan sertifikasi, program ini dilaksanakan sekolah guna mengembangkan kemampuan guru yang mengajar tidak sesuai dengan latar belakang pendidikannya atau bukan berasal dari program pendidikan keguruan.

Selanjutnya dilakukan juga upaya pengembangan pada program pemberdayaan MGMP (Musyawarah Guru Mata Pelajaran), program ini dilaksanakan sekolah karena MGMP diharapkan akan meningkatkan profesionalisme guru dalam melaksanakan pembelajaran yang bermutu sesuai kebutuhan peserta didik.

Pada pelaksanaan pelatihan dan pengembangan disekolah ini pelaksanaan pelatihan dan pengembangan sudah dilaksanakan namun belum terlaksana dengan baik, contoh masih ada guru yang mengajar tidak sesuai dengan kaulifikasi yang dimiliki. Dengan demikian berdasarkan hasil pra sursey tersebut menunjukkan bahwasannya Pelatihan dan pengembangan profesionalisme guru telah melaksanakan komponen-komponen dalam pengembangan profesionalisme guru serta telah memenuhi segala proses dalam pengembangan profesionalisme guru tersebut, namun belum melaksanakan secara maksimal. Dalam upaya meningkatkan kompetensi yang harus dimiliki guru tersebut, maka dibutuhkan pengembangan yang lebih baik. Sehingga penulis tertarik

\section{METODE PENELITIAN}

Penelitian ini merupakan jenis penelitian kualitatif yaitu suatu Pendekatan Penelitian yang menghasilkan data dekriptif berupa data-data tertulis atau lisan dari orang-orang dan pelaku yang diamati. Adapun bentuk penelitiannya adalah deskriptif yaitu penelitian yang dilakukanhanya bertujuan untuk menggambarkan keadaan atau status fenomena dalam situasi tertentu. Data merupakan hal yang esensi untuk menuatkan suatu permasalahan dan juga diperlukan untuk menjawab masalah penelitian. Peneliti memperoleh data yang ada kaitannya judul yang terkait, dengan cara memperoleh data yang obyektif sesuai dengan sasaran yang menjadi obyek penelitian, dan sumber data tersebut diperoleh dari :

1. Data primer. yaitu yang bersumber dari informan yang mengetahui secara jelas dan rinci mengenai masalah yang sedang diteliti. Informan adalah orang yang dimanfaatkan untuk memberikan nformasi tentang situasi dan kondisi dalam penelitian. Data primer dalam penelitian ini diperoleh dari data data yang didapat dari hasil wawancara dengan informan yaitu; a) Kepala Madrasah, b) Guru Kelas

2. Data sekunder, yaitu data yang diperoleh selama melaksanakan study kepustakaan, berupa literatur maupun data tertulis yang berkenaan dengan penelitian di tesis ini. 
Data adalah bahan mentah yang dikumpulkan peneliti dari lapangan penelitian. Data merupakan bahan spesifik dalam melakukan analisis. Untuk memperoleh data yang valid, maka di dalam penelitian ini penulis menggunakan metode pengumpulan data sebagai berikut:

1. Metode Observasi. Menurut Suharsimi Arikunto,Observasi atau pengamatan meliputi kegiatan pemuatan perhatian terhadap suatu obyek dengan menggunakan seluruhalat indera. Mengobservasi dapat dilakukan melalui penglihatan,penciuman, pendengaran, peraba dan pengecap. Observasi dapat dilakukan dengan tes, Kuesioner, rekaman gambar, daan rekaman suara. Observasi ialah metode pengumpulan data dengan jalan pengamatan secara sistematik terhadap fenomena-fenomena yang ada. Dari teknik ini penulis menggunakannya untuk memperoleh data tentang kondisi lingkungan MAS Al- Manshuriyah Metode Wawancara (Interview) . Metode wawancara adalah proses tanya jawab secara lisan yang mempertemukan dua orang atau lebih dan terjadi tatap muka. Dalam hal ini eneliti tidak hanya mengamati dari luar saja, akan tetapi juga menanyakan secaralangsung kepada pihak yang terkait seperti; kepala Madrasah dan Guru Kelas.

2. Metode Dokumentasi. Metode dokumentasi sama pentingnya dari teknik pengumpulan data yang lainnya..Dokumentasi adalah mencari data mengenai hal-hal atau variable atau catatan transkrip, buku-buku, surat kabar, majalah, prasasti, notulen rapat, leger, agenda dan lain-lain.

Analisis data adalah proses penyederhanaan data kedalam bentuk yang lebih mudah dibaca dan diinterpretasikan. Dalam penelitian kualitatif yang dibuat peneliti menggunakan analisa logika komparatif abstraktif yaitu suatu logika yang menggunakan cara perbandingan. konseptualisasi, kategorisasi dan deskripsi dikembangkan atas dasar kejadian (incidence) yang diperoleh ketika kegiatan lapangan berlangsung. Analisis penelitian ini dilakukan secara terus menerus sejak dari awal penelitian sampai dengan selesainya penelitian ini. Jadi semenjak memperoleh data dari lapangan baik dari hasil observasi, wawancara atau dokumentasi, peneliti langsung mempelajari dan merangkum, ditelaah dan dianalisis sampai selesainya penelitian. Selanjutnya alur analisis data yang penulis gunakan adalah:

1. Reduksi data yaitu proses memilih, menyederhanakan, memfokuskan, dan mengubah data kasar kedalam catatan lapangan. Istilah reduksi data dalam penelitian kualitatif disejajarkan maknanya dengan pengelolaan data.

2. Penyajian data yaitu suatu cara merangkum data yang memudahkan untuk menyimpulkan hasil penelitian.

3. Menarik kesimpulan dan verifikasi dari pengumpulan data. Dengan demikian pekerjaan mengumpulkan data bagi penelitian kualiatif harus langsung diikuti dengan pekerjaan menulis, mengedit, mengklasifikasi, mereduksi, dan 
menyajikan data, serta menarik kesimpulan dengan cara membandingkan sebagai analisis data kualitatif.

Dalam penelitian kualitatif umumnya lebih melihat proses daripada produk dari obyek penelitiannya. Kemudian dari pada itu kesimpulan dari data kualitatif tidak berupa angka-angka tetapi disajikan dalam bentuk kata verbal yang pengolahannya mulai dari mengedit sampai menyajikan dalam keadaan ringkas dikerjakan di lapangan.

\section{HASIL PENELITIAN}

Dalam menjalankan tugas pokok dan fungsi memang harus disiplin sebab hal ini kunci utama dalam bekerja. Hasil wawancara dengan salah seorang guru, yakni sebagai berikut:

"memang untuk menjalankan tugas pokok dan fungsi dengan disiplin tidak terlepas dari kebijakan kepala sekolah dalam membuat peraturan sekolah, sebab dengan peraturan yang tepat dan baik, maka akan menjadi pedoman bagi kami dalam menjalankan tugas dengan baik pula"

Penerapan kebijakan kepala sekolah dalam meningkatkan professional guru sangatlah diharapkan berjalan dengan baik, sebab dengan kebijakan yang telah dibuat, maka otomatis harus dilaksanakan dengan baik pula. Hasil wawancara dengan salah seorang guru, yakni sebagai berikut:

"memang kebijakan kepala sekolah ada yang menguntungkan kami guru, namun tidak sepenuhnya, sehingga perlu inovasi dan pembaharuan kebijakan kepala sekolah, sehingga keputusan yang diambil dapat sepenuhnya dijalankan oleh guru"

Disamping itu juga hendaknya kebijakan kepala sekolah dapat menjadi solusi dalam permasalahan peningkatan SDM Madrasah. Hasil wawancara dengan salah seorang guru yakni sebagai berikut:

“80 \% kebijakan kepala sekolah berdampak positifi terhadap peningkatan kualitas guu, seperti memberikan pelatihan dan pembinaan, kemudian sedikit memperhatikan kesejahteraan guru"

Dalam membuat kebijakan tentunya kepala sekolah dapat menganalisis terlebih dahulu permasalahan dalam peningkatan kualitas guru, dengan menganalisis situasi yang ada maka kepala sekolah dapat menentukan kebijakan yang tepat untuk peningkatan kualitas guru, namun jika kepala sekolah mengabaikan analisis dilapangan, maka kebijakan yang diambil akan kurang tepat sasaran. Hasil wawancara dengan kepala sekolah yakni, sebagai berikut: 
"saya dalam membuat kebijakan terutama dalam peningkatan kualitas guru, selalu melihat kondisi permasalahan yang ada, dan kemudian saya baru menentukan kebijakan yang tepat dalam mengatasi permasalahaan kinerja guru

Kebijakan yang diambil tentunya juga tidak hanya berdasarkan kondisi dan permasalahan yang ada, namun musyawarah dan mufakat antar sesame warga sekolah sangatlah penting juga, sebab dalam melaksanakan kebijakan tentunya melibatkan semua warga sekolah, jika warga sekolah kurang menyepakati kebijakan yang diambil, maka kebijakan tersebut kurang dapat berjalan dengan baik. Hasil wawancara dengan salah seorang guru, yakni sebagai berikut:

"memang benar dalam menentukan kebijakannya kepala sekolah selalu mendiskusikan dengan kami, sehingga semua sepakat untuk mejalakannya, dan kebijakan yang diambil tepat sasaran"

Peran pengawas sekolah sangatlah penting sekali dalam mengawasi kebijakan kepala sekolah, sebab pengawas sekolah dapat memberikan masukkan dan arahan tentang kebijakan yang diambil, sehingga kepala sekolah dapat menerapkan kaebijakan sekolah dengan baik. Hasil wawancara dengan pengawas sekolah, yakni sebagai berikut:

"kepala madrasah tentunya sering sharing kepada saya dalam membuat kebijakan dan keputusan tentang peningkatan professional guru dalam mengajar, sehingga dalam penerpan kebijakan dapat tepat sasaran dan tujuan dari kebijakan yang diambil sesuai dengan keinginan"

Dalam penerapan kebijakan tentunya ada yang berjalan dengan baik dan ada yang kurang berjalan dengan baik, sehingga hal ini menuntut pembuat kebijakan untuk selalu berinovasi agar kebijakan yang diambil berikutnya dapat tepat sasaran. Namun jika kepala sekolah tidak mau berinovasi, maka kebijakan yang diambil kurang dapat berjalan dengan baik. Hasil wawancara dengan salah seorang guru, yakni sebagai berikut:

"faktor yang yang terpnting kurang berjalannya kebijakan yang telah dibuat adalah sanksi yang dirterapkan kurang berjalan dengan baik, sehingga menuntut kepala sekolah untuk memberikan sanksi yang tepat agar yang melanggar kebijakan tidak mengulanginya kembali dan menjalan dengan baik kebijakan yang telah dibuat"

Evaluasi kebijakan kepala sekolah dalam meningkatkan professional guru dalam menjalankan tugas sangatlah penting sekali, sebab melalui kebijakan yang 
tepat, maka akan berdampak pada peningkatan kualitas guru dalam menjalankan tugasnya dengan baik, namun jika kebijakan yang dibuat kurang tepat, maka akan berdampak pada peningkatan kualitas guru dalam menjalankan tugasnya dengan baik.

\section{PEMBAHASAN}

Kebijakan kepala sekolah dalam meningkatkan professional guru dalam menjalankan tugasnya $80 \%$ berjalan dengan baik, namun ada sedikit yang perlu diperbaruai sehingga kebijakan tersebut dapat berjalan dengan baik, yakni pemberian sanksi yang tepat, peran pengawas sekolah dan musyawarah dalam menerapkan kebijakan terutama dalam meningkatkan professional guru dalam menjalankan tugas pokok dan fungsinya dengan baik.

Berjalanya kebijakan yang diterapkan tidak dapat terlepas dari peran kepala sekolah. Kepala madrasah pada hakikatnya adalah guru yang diberi tugas tambahan. Kepala madrasah merupakan salah satu komponen pendidikan yang paling berperan dalam meningkatkan kualitas pendidikan. Mulyasa menyatakan bahwa; "erat hubungannya antara mutu Kepala madrasah dengan berbagai aspek kehidupan madrasah seperti disiplin madrasah, dan iklim madrasah". Kepala madrasah harus mampu menciptakan suasana yang kondusif dan inovatif dalam melaksanakan kegiatan di madrasah. Hal ini sesuai dengan Peraturan Menteri Pendidikan Nasional Nomor 13 Tahun 2007 tentang Standar Kepala Sekolah/Madrasah, disebutkan bahwa "Kepala madrasah mengelola guru dan staf dalam rangka pendayagunaan semberdaya manusia secara optimal, menciptakan budaya dan iklim madrasah yang kondusif dan inovatif bagi pembelajaran”.

Kepala madrasah harus memiliki visi, misi, kreatif serta inovatif dan berorientasi pada mutu. Strategi ini merupakan usaha sistematik Kepala madrasah secara terus menerus untuk memperbaiki kualitas layanan sehingga fokusnya diarahkan pada guru dan tenaga kependidikan lainnya agar lembaga kependidikan yang dipimpinnya dapat berjalan dengan baik. Sebagai pimpinan di madrasah, peran dan tanggung jawab Kepala madrasah sangat strategis dalam meningkatkan kinerja guru maupun tenaga kependidikan lainnya.

Peran dan fungsi Kepala madrasah dalam meningkatkan kinerja guru sangat penting. Hal ini sesuai dengan pendapat Mulyasa, bahwa: "Kepala madrasah dituntut untuk senantiasa berusaha membina dan mengembangkan hubungan kerjasama yang baik antara madrasah dan masyarakat guna mewujudkan madrasah yang efektif dan efisien. Kepala madrasah harus mampu menjalin hubungan kerjasama baik sesama warga madrasah maupun dengan masyarakat lingkungan madrasah".

Dari kutipan diatas dapat disimpulkan bahwa tugas Kepala madrasah untuk melakukan komunikasi dengan bawahannya untuk meningkatkan kinerja dan kualitas kerja. Melalui jalinan kemitraan yang baik maka fungsi Kepala madrasah sebagai innovator dan motivator memiliki peran strategis yang tepat 
untuk menjalin komunikasi yang harmonis dengan lingkungannya, mencari gagasan baru, mengintegrasikan setiap kegiatan, memberikan teladan kepada seluruh tenaga kependidikan di madrasah yang ia pimpin.

Sebagai pemimpin, Kepala madrasah juga harus memiliki strategi yang tepat untuk memberikan motivasi kepada guru dalam melaksanakan tugas dan fungsinya. Motivasi ini dapat ditumbuhkan melalui pengaturan lingkungan yang baik, pengaturan suasana yang kondusif dan komunikatif, disiplin yang sinergis sesama komponen warga madrasah. Beberapa prinsip yang dapat diterapkan oleh Kepala madrasah dalam meningkatkan kinerja guru sebagai tenaga kependidikan agar mampu meningkatkan kemampuan profesionalnya. Prinsip-prinsip tersebut sebagaimana disebut oleh Mulyasa (20120 adalah sebagai berikut:

1. Para tenaga kependidikan akan bekerja lebih giat apabila kegiatan yang dilakukan menarik dan menyenagkan.

2. Tujuan kegiatan perlu disusun dengan jelas dan diinformasikan kepada para tenaga kependidikan sehingga mereka mengetahui tujuan ia bekerja. Para tenaga kependidikan juga harus dilibatkan dalam penyusunan tujuan tersebut.

3. Para tenaga kependidikan harus selalu diberitahu tentang hasil dari setiap pekerjaannya.

4. Pemberian hadiah lebih baik dari pada hukuman namun sewaktu-waktu hukuman juga perlu dilakukan.

5. Usahakan untuk memenuhi kebutuhan tenaga kependidikan dengan jalan memperhatikan kondisi fisiknya, memberikan rasa aman, menunjukkan bahwa Kepala madrasah memperhatikan mereka, mengatur pengalaman sedemikian rupa sehingga setiap pegawai memperoleh kepuasan dalam pekerjaan.

\section{SIMPULAN}

Kebijakan kepala sekolah dalam meningkatkan professional guru dalam menjalankan tugasnya berjalan dengan baik, namun ada sedikit yang perlu diperbaruai sehingga kebijakan tersebut dapat berjalan dengan baik, yakni pemberian sanksi yang tepat, peran pengawas sekolah dan musyawarah dalam menerapkan kebijakan terutama dalam meningkatkan professional guru dalam menjalankan tugas pokok dan fungsinya dengan baik 


\section{DAFTAR PUSTAKA}

Fathoni, A.(2006). Manajemen Sumber Daya Manusia, Jakarta : Rineka Cipta

Hamalik, O. (2009). Pendidikan Guru Berdasarkan Pendekatan Kompetensi, Jakarta : PTBumi Aksara

Mulyasa, E., (2012). Manajemen dan Kepemimpinan Kepala Sekolah. Jakarta: Bumi Aksara

Pidarta, M (2011). Manajemen Pendidikan Indonesia, Jakarta: Rineka Cipta Tim Dosen Administrasi UPI, (2011). Manajemen Pendidikan, Bandung : Alfabet

Undang-undang Republik Indonesia Nomor 14 Tahun 2005 tentang Guru dan Dosen

Usman, (1995). Menjadi Guru Profesional, Bandung : Remaja Rosdakarya 